\title{
Early indirect selection for nitrogen use efficiency in maize ${ }^{1}$
}

\author{
Seleção precoce e indireta para eficiência no uso de nitrogênio em milho
}

\author{
Débora Santos Caixeta ${ }^{2 *}$, Roberto Fritsche-Neto ${ }^{3}$, Ítalo Stefanine Correia Granato ${ }^{4}$, Lucimar Rodrigues de \\ Oliveira $^{5}$ e João Carlos Cardoso Galvão 6
}

\begin{abstract}
Several studies to evaluate nitrogen use efficiency (NUE) have been carried out using early growth stages. However, there are no scientific reports on the ideal stage for evaluation and on which characteristics have the highest correlation with the NUE at that stage. The aim therefore was to identify the phenological stages and secondary characteristics which maximize accuracy in early indirect selection for NUE in maize. To do this, three endogamic maize strains were evaluated in a completely randomised design with five replications, in a triple factorial scheme (strains $\mathrm{x} \mathrm{N}$ levels $\mathrm{x}$ phenological stage), at two contrasting nitrogen levels: low and high nitrogen. The plants were evaluated at five growth stages: stage nine (V9), with 14 fully-developed leaves (V14), tasseling (VT), flowering (R1) and physiological maturity (R6). The following characteristics were evaluated: efficiency in the usage, absorption, use and translocation of nitrogen; activity of nitrate reductase and glutamine synthetase; length of the lateral and axial roots; specific root area; chlorophyll content; number of leaves; plant height; stem diameter; and the levels of phosphorus and potassium. Considering the estimated direct and indirect gains, it can be concluded that the activities of glutamine synthetase at the V9 and V14 stages permit early indirect selection for nitrogen use efficiency in maize under conditions of low and high $\mathrm{N}$ availability respectively.
\end{abstract}

Key words: Zea mays. Path analysis. Abiotic stress. Plant breeding.

RESUMO - Vários trabalhos de avaliação de eficiência no uso de nitrogênio (EUN) já foram feitos utilizando estádios precoces. Contudo, não há relatos científicos sobre o estádio ideal e, neste, quais caracteres que apresentam maior correlação com a EUN. Assim, o objetivo foi identificar os estádios fenológicos e os caracteres secundários que maximizam a acurácia na seleção precoce e indireta para a EUN em milho. Para isso, foram avaliadas três linhagens endogâmicas de milho em delineamento inteiramente casualizado, com cinco repetições, em esquema fatorial triplo (linhagens x níveis de $\mathrm{N} \mathrm{x}$ estádio fenológico), em duas doses contrastantes de nitrogênio - baixo e alto nitrogênio. As plantas foram avaliadas em cinco estádios fenológicos sendo eles: nove (V9) e 14 folhas completamente desenvolvidas (V14), pendoamento (VT), florescimento (R1) e maturidade fisiológica (R6). Foram avaliados os caracteres: eficiência na utilização, na absorção, no uso e na translocação de nitrogênio, atividade da nitrato redutase e da glutamina sintetase, comprimento de raiz lateral e axial, área de raiz específica, teor de clorofila, número de folhas, altura de planta, diâmetro de colmo, teor de fósforo e potássio. Considerando os ganhos diretos e indiretos estimados, conclui-se que as atividades da glutamina sintetase, nos estádios V9 e V14, permitem a seleção precoce e indireta para eficiência no uso de nitrogênio em milho, nas condições de baixa e alta disponibilidade de $\mathrm{N}$, respectivamente.

Palavras-chave: Zea mays. Análise de trilha. Estresse abiótico. Melhoramento vegetal.

\footnotetext{
DOI: $10.5935 / 1806-6690.20150016$

*Autor para correspondência

${ }^{1}$ Recebido para publicação em 19/07/2013; aprovado em 12/12/2014

Parte da Dissertação de Mestrado do primeiro autor apresentada ao Programa de Pós-Graduação em Fitotecnia da Universidade Federal de Viçosa-MG

${ }^{2}$ Faculdade do Noroeste de Minas-FINOM e Faculdade Patos de Minas-FPM, Patos de Minas-MG, Brasil, deborascaixeta@gmail.com

${ }^{3}$ Departamento de Genética, Laboratório de Melhoramento de Plantas Alógamas, Escola Superior de Agricultura Luiz de Queiroz, ESALQ/USP,

Piracicaba-SP, Brasil, roberto.neto@usp.br

${ }^{4}$ Departamento de Genética, Laboratório de Melhoramento de Plantas Alógamas, Escola Superior de Agricultura Luiz de Queiroz, ESALQ/USP,

Piracicaba-SP, Brasil, italo.granato@gmail.com

${ }^{5}$ Analista Ambiental Agência Avançada, Instituto Estadual de Florestas/IEF, Capitólio-MG, Brasil, lucimaror@yahoo.com.br

${ }^{6}$ Departamento de Fitotecnia, Universidade Federal de Viçosa/UFV, Viçosa-MG, Brasil, jgalvao@ufv.br
} 


\section{INTRODUCTION}

Considering only those areas which are suitable for its cultivation, maize production will not be enough to meet world demand for this cereal in the coming decades (FRITSCHENETO; BORÉM, 2011). In addition, approximately $50 \%$ of the areas under cultivation are in tropical climates, where conditions of low natural soil fertility and drought predominate (MONNEVEUX et al., 2005). In this context, there are alternatives which can be adopted in order to increase maize production in Brazil, such as the use of off-season crops, the use of cultivars with higher productivity, or even the expansion of farming to lands of the cerrado region. However, some areas of the cerrado impose limitations on agricultural production due to their low soil fertility, especially nitrogen (N). Nevertheless, it is important to note that $\mathrm{N}$ is among the main nutrients responsible for increases in maize productivity (RICHARDSON et al., 2009), playing an important part in the metabolism of the plant, especially in protein synthesis (JAKELAITIS; SILVA; FERREIRA, 2005; PAVINATO et al., 2008).

Additionally in recent years, interest in sustainable agriculture has encouraged breeding programs to develop cultivars that show greater efficiency in the use of nutrients, i.e. cultivars displaying satisfactory productivity under conditions of nutritional stress, with consequently lower production costs and environmental impact.

Moll, Kamprath and Jackson (1982) defined nitrogen use efficiency (NUE) as grain or dry-shoot yield per unit of nutrient available to the plant. NUE comprises nitrogen uptake efficiency (NUpE) and nitrogen usage efficiency (NUtE). UpE is the ability of the genotype to absorb the nutrient from the soil, while UtE refers to the ability of the genotype to produce biomass or grains using the absorbed nutrient. Greater values for NUE could therefore be achieved by increasing the UpE and/or UtE (CHEN et al., 2009). According to DoVale et al. (2012), regardless of the availability of $\mathrm{N}$, absorption efficiency is the most important component of nitrogen use efficiency. Those researchers also state that regardless of the availability of $\mathrm{N}$, genetic differences as regards NUE are a result of the NUpE. It is therefore important, in breeding programs which aim to increase NUE, for the characteristic used in early selection of superior materials to have a high correlation with the NUpE at the end of the crop cycle. This ensures high productivity and high protein levels in the grain.

The use of methods of early evaluation, or of indirect selection for conditions of abiotic stress, are of great interest as they speed up the selection process, promptly discarding highly susceptible genotypes and enabling resources to be focused on those which are potentially superior (FRITSCHE-NETO et al., 2010). Because of this, secondary characteristics related to nitrogen use efficiency (NUE) have been used with the aim of increasing the efficiency of the selection process. In that context, the ideal secondary characteristic is one that is genetically correlated with the NUE under stress, that displays high heritability, has high genetic variability, is easy and quick to evaluate, and is stable during the period of measurement, as well as being observed before flowering, so that there is no recombination of undesirable parents (O'NEILL; SHANAHAN; SCHEPERS, 2006). In this respect, the activities of enzymes related to the metabolism of N can be highlighted (GALLAIS; HIREL, 2004); also the activities of the root system, where root length may be an indicator of the potential for water and nutrient uptake.

Given the above, the objective was to identify the growth stages and secondary characteristics which maximize accuracy in early indirect selection for nitrogen use efficiency in maize.

\section{MATERIAL AND METHODS}

\section{Genetic material and conducting the experiment}

Three fully endogamous strains of maize were evaluated in a completely randomised design, with five replications, in a triple factorial scheme (strains $x$ levels of $\mathrm{N} x$ growth stage), at two contrasting nitrogen dosages: low nitrogen (LN) corresponding to $12.5 \mathrm{mg} \mathrm{dm}^{-3}$ urea; and high nitrogen (HN) corresponding to $750 \mathrm{mg} \mathrm{dm}^{-3}$ urea. The strains are from the germplasm bank of Programa Milho®, and were previously identified as being efficient, intermediate, and inefficient in the use of nitrogen.

The experiment was set up in a greenhouse at the Federal University of Viçosa, in the state of Minas Gerais, Brazil (MG), from January to May, 2012. Each lot consisted of one plant per pot of 20 litres containing a substrate composed of $50 \%$ washed sand and $50 \%$ soil from a B horizon of a dystrophic Red-Yellow Latosol, providing negligible amounts of N. Due to this, the values found in soil analysis were disregarded. The seeds were placed into trays to germinate and after five days the best seedlings were transplanted to the pots.

Basic fertilisation was carried out using potassium and phosphorus. Nitrogen fertilisation was by instalments, and followed the nutrient uptake curve of the maize (DUARTE et al., 2003). At each growth stage for which collections were made therefore, enough $\mathrm{N}$ was provided to meet plant demand up to that stage only. High availability and stress dosages had been defined in an earlier experiment as $60 x$ the ratio of the two. That experiment was carried out in a completely randomised design, in a $4 \times 2$ factorial scheme (4 dosages of $\mathrm{N} \times 2$ contrasting strains), with two replications; the nitrogen content of the plant being the characteristic evaluated. 
Regression analysis was later performed to identify the dosages for high and low nitrogen availability. Low N was considered the dosage at which grain yield in the strains was reduced on average by $50 \%$.

The plants were evaluated (collected) at five growth stages, namely: nine fully developed leaves (V9), 14 fully developed leaves (V14), tasselling (VT), flowering (R1) and physiological maturity (R6).

For each of the five stages being considered, the plants were harvested, the root system was separated from the shoot and the following evaluations performed:

1) Determination of nitrate reductase (NR) activity: by quantifying the nitrite produced per hour, per gram of shoot fresh weight ( $\mu$ moles $\left.\mathrm{NO}_{2}{ }^{-} \mathrm{h}^{-1} \mathrm{~g}^{-1} \mathrm{FW}\right)$. The procedure consists in infiltrating the tissue with a solution containing nitrate, followed by measurement of the nitrite produced by the reaction and which diffuses into the incubation medium. To do this, discs were cut from leaves located on the middle third of the plants. The discs were placed into containers of the incubation medium, which consisted of $0.1 \mathrm{M}$ phosphate buffer $\mathrm{pH} 7.5,1 \%$ propanol and $0.1 \mathrm{M}$ potassium nitrate. The containers were then incubated in a water bath at $32{ }^{\circ} \mathrm{C}$. During the reaction, the containers were kept in the dark to avoid use of the nitrite formed in the reaction which was catalysed by the NR. After 60 minutes, a $1 \mathrm{ml}$ aliquot part of the reaction medium was removed and placed into a tube containing $2.4 \mathrm{ml}$ of distilled water, $0.3 \mathrm{ml}$ of $1 \%$ (w/v) sulfanilamide in $3 \mathrm{~N} \mathrm{HCl}$, and $0.3 \mathrm{ml} 0.02 \% \mathrm{~N}-(1-$ naphthyl) ethylenediamine dichloride. The amount of nitrite $\left(\mathrm{NO}_{2}\right)$ produced was determined colourimetrically by reading the absorbance of the solutions at $540 \mathrm{~nm}$. The amount of $\mathrm{NO}_{2}$ was calculated using a standard curve in the concentration range of $10^{-2}$ to $10^{-1} \mu \mathrm{mol} \mathrm{NO}$;

2) Determination of glutamine synthetase (GS) activity: by quantifying the glutamyl hydroxamate per hour, per gram of shoot (GSs) and root (GSr) fresh weight ( $\mu$ moles glutamyl hydroxamate (GHD) hour $\left.^{-1} \mathrm{~g}^{-1} \mathrm{FW}\right)$. The activity can be measured from the synthetase reaction dosing the formation of $\mu$-glutamyl hydroxamate from glutamate and hydroxylamine. The reaction medium used to evaluate enzyme activity by the synthetase reaction was $500 \mathrm{mM}$ glutamate, $60 \mathrm{mM}$ hydroxylamine, $200 \mathrm{mM} \mathrm{MgSO}$, $80 \mathrm{mM}$ ATP and $50 \mathrm{mM}$ imidazole buffer $\mathrm{pH}$ 7.4. For the transferase reaction a reaction medium was used which contained $65 \mathrm{mM}$ glutamine, $17 \mathrm{mM}$ hydroxylamine, $33 \mathrm{mM}$ sodium arsenate, $4 \mathrm{mM} \mathrm{MnCl}_{2}, 1.7 \mathrm{mM} \mathrm{ADP}$ and $100 \mathrm{mM}$ imidazole buffer $\mathrm{pH}$ 6.8. After macerating the leaf discs with the previously frozen roots in the reaction medium, the macerate was placed into an Eppendorf tube and centrifuged at $110,000 \mathrm{rpm}$ for 30 minutes at $4{ }^{\circ} \mathrm{C}$. After centrifugation, a $1 \mathrm{~mL}$ aliquot part of the supernatant was removed and placed into another Eppendorf tube which already contained the reaction medium, and placed into a water bath at $30{ }^{\circ} \mathrm{C}$, the reaction being completed by the addition of the enzyme $(0.25 \mathrm{ml})$. After 20 minutes the reaction was halted by adding $1 \mathrm{ml}$ of a reagent containing $0.67 \mathrm{~N} \mathrm{HCl}, 0.20 \mathrm{~N}$ trichloroacetic acid and $0.37 \mathrm{M} \mathrm{FeCl}_{3}$. Once the reagent had been added to the supernatant in the test tube, a $2 \mathrm{ml}$ aliquot part was removed, which was again placed into an Eppendorf tube and centrifuged at $100,000 \mathrm{rpm}$ for 5 minutes at $4{ }^{\circ} \mathrm{C}$. The amount of $\mu$-glutamyl hydroxamate formed was then evaluated using a spectrophotometer at a wavelength of 540 $\mathrm{nm}$ for the absorbance readings;

3) Determination of shoot dry weight (SDW, g), root dry weight (RDW, g), grain dry weight (GDW, g) and total dry weight (TDW, g). Nitrogen levels and later, nitrogen content, were determined for the shoots $(\mathrm{Ns})$, roots $(\mathrm{Nr})$ and grains $(\mathrm{Ng})$, as well as for total $\mathrm{N}(\mathrm{Nt})$. The levels of $\mathrm{N}$ were obtained by sulphuric acid digestion of samples of the shoots, roots and grain. Once the data on dry mass and $\mathrm{N}$ levels were obtained, and from the amount of nitrogen supplied (Np), efficiency in the absorption, utilisation, use and translocation of nitrogen was estimated according to Moll, Kamprath and Jackson (1982) (Equations 1, 2, 3 and 4):

$$
\begin{aligned}
& N U t E=\frac{T D W}{N t} \\
& N U p E=\frac{N t}{N p} \\
& N T r E=\frac{N g}{N t} \\
& N U E=N U E \times N U p E=\frac{T D W}{N p}
\end{aligned}
$$

where: NUtE is the nitrogen usage efficiency, NUpE the nitrogen uptake efficiency, NUE the nitrogen use efficiency, NTrE the nitrogen translocation efficiency, TDW the total dry weight, Nt the total nitrogen content of the plant, $\mathrm{Ng}$ the nitrogen content of the grain, and $\mathrm{Np}$ the amount of nitrogen supplied to the plant;

4) Determination of phosphorus levels in the shoots (PLs, dag $\mathrm{kg}^{-1}$ ), roots (PLr, dag $\mathrm{kg}^{-1}$ ) and grain (PLg, dag kg-1), and total phosphorus (TP, dag $\mathrm{kg}^{-1}$ ), as used by DoVale et al. (2013);

5) Determination of potassium levels in the shoots (KLs, dag kg-1), roots (KLr, dag $\mathrm{kg}^{-1}$ ) and grain (KLg, dag kg-1), and total potassium (TK, dag $\mathrm{kg}^{-1}$ ), as per the method used in determining the P levels;

6) Determination of lateral root length (LRLat, $\mathrm{cm}$ ), axial root length (LRAxi, $\mathrm{cm}$ ) and specific root area (SRA, $\mathrm{cm}^{2} \mathrm{~g}^{-1}$ ). Root length and area were obtained with the WinRHIZO 4.1 image analyser, coupled to a 
professional Epson XL 10000 Scanner equipped with an additional light unit (TPU). Roots with a diameter less than or equal to $0.5 \mathrm{~mm}$ were considered lateral roots, and those over $0.5 \mathrm{~mm}$ were considered axial roots (TRASCHSEL et al., 2009). Specific root area was later estimated (SRA, $\mathrm{cm}^{2} \mathrm{~g}^{-1}$ ) according to equation 5:

$$
S R A=\frac{R A}{R D W}
$$

where: RA is the total root area (fine roots + coarse roots) and RDW the root dry weight;

7) Determination of phenological characteristics: number of leaves (NL), plant height $(\mathrm{PH}, \mathrm{cm})$, stem diameter ( $\mathrm{SD} \mathrm{cm}$ ), chlorophyll levels (SPAD, $\mu \mathrm{g} \mathrm{cm}^{-2}$ ), number of kernel rows per ear (ROW), 1000-grain weight $(\mathrm{GW}, \mathrm{g})$ and ear height $(\mathrm{EH}, \mathrm{cm})$.

\section{Statistical and genetic analysis}

It was found that some characteristics did not have a normal distribution. Data transformation was therefore performed. For the variables NUpE, NUtE and NUE, $\sqrt{ }(X+0,5)$ was used. For LRLat and LRAxi, $\log (\mathrm{X}+1)$ was used.

Variance analysis (ANOVA) was later carried out individually (for each level of $\mathrm{N}$ within each stage), on the sets from each stage and on the overall set involving all three factors (three strains $\mathrm{x}$ two levels of $\mathrm{N} x$ five growth stages). In these analyses, the effect of strain (L) was considered to be random, and those of growth stage (S) and availability of $\mathrm{N}$ in the soil $(\mathrm{N})$ as fixed. Except for the interaction $\mathrm{E} x \mathrm{~N}$, all were considered as having a random effect (data not shown).

For those characteristics which were significant by ANOVA, a diagnosis was then made of multicollinearity between the explicative characteristics; their degree in the correlation matrix being established based on condition number. Subsequently, by means of path analysis, breakdowns were made of the phenotypic correlations for low $\mathrm{N}$ availability, for the direct and indirect effects of the characteristics LRLat, LRAxi, SRA, NR, GSs, GSr, SPAD, NL, PH, SD, TP, TK, NTrE (explicative variables) on the characteristic NUE and its components NUpE and NUtE (dependent variables), according to their significance at each stage under evaluation (tables not shown). Finally, gains were estimated for the dependent variables at the two levels of $\mathrm{N}$, with direct (GSd) and indirect selection (GSi) of the explicative variables.

The analyses were performed using the Genes Software for Genetics and Experimental Statistics (CRUZ, 2013) and the Statistical Analysis System (SAS) version 9.1 (SAS INSTITUTE, 2003).

\section{RESULTS AND DISCUSSION}

\section{Path analysis}

By means of path analysis, it was sought to quantify the effect of the secondary characteristics during the growth stages being analysed, on the NUpE at the R6 stage.

At stage V9, under low $\mathrm{N}$ availability, a high direct effect was seen from the GSs on the NUpE at R6 (2.55) in relation to the residual effect $(0.01)$ (Table 1$)$. This indicates that plants with high GSs activity early in the cycle will present high values for $\mathrm{NUpE}$ at the end of the cycle, with a consequently high NUE. High GSs activity makes the process of $\mathrm{N}$ assimilation more efficient. Signals are sent to the plant that the absorption process should continue as there is no accumulation of $\mathrm{NH}_{4}^{+}$. This could generate negative feedback, reducing the absorption rate, besides being a toxic substrate for the plants at high concentrations. From the high coefficient of determination (0.99), it was also seen that the characteristics GSs, LRAxi and TP explain almost the total variation in NUpE.

In addition to GSs, the characteristic LRAxi was also potentially efficient in the early and indirect selection for NUpE at R6 due to its high direct effect (1.63). However, the use of the two characteristics GSs and LRAxi simultaneously in order to increase the accuracy of the selection process, is not possible, as they have negative indirect effects on each another (-1.39 and -2.17). Increasing the GSs is therefore the most appropriate method because it is not destructive, allowing the plants that were evaluated to intercross, a situation which is not possible when evaluating plants for LRAxi.

At stage V14 under low $\mathrm{N}$ availability, the characteristics TP and TK explain all the phenotypic variation for the NUpE at R6 $\left(\mathrm{R}^{2}=1.00\right)$ (Table 2). For indirect selection at the beginning of the cycle, it is seen that genotypes with high levels of $\mathrm{P}$ and low levels of $\mathrm{K}$ are correlated with a high $\mathrm{NUpE}$ at the end of the cycle (0.61). This high negative correlation of $\mathrm{K}$ with NUpE lies in the fact that excess potassium restricts $\mathrm{N}$ uptake. However, it is known that $\mathrm{K}$ is related to the activity of the enzyme NR, due to being associated with the regulation and uptake of nitrate by the plant roots. According to Silva et al. (2011), when nitrate is reduced in the leaves, malate is formed in response to the increased internal $\mathrm{pH}$ of the tissue. According to the same authors, part of the malate is transferred to the phloem, accompanied by potassium, to be translocated to the roots, where it undergoes decarboxylation. The carbonic acid produced is released into the environment in exchange for the absorbed nitrate, in that way controlling the absorption of the nitrate. The recirculated potassium serves as a counterion for the transport of nitrate in the xylem to the shoots. It is therefore of great importance to maintain the $\mathrm{K}$ content of the substrate at optimal levels, so that there is no negative interference with the absorption of $\mathrm{N}$. 
The relation of $\mathrm{P}$ to $\mathrm{NUpE}$ has been demonstrated in several studies. Among them, Alves et al. (1996) observed a substantial reduction in levels of total $\mathrm{N}$ in maize plants exposed to increasing periods of Pomission in a nutrient solution. This is due to the importance of $\mathrm{P}$ as a constituent of adenosine triphosphate (ATP), generating the necessary energy for the activation of GS, since the assimilation of this nutrient is a highly demanding process in terms of energy, requiring the transfer of two electrons per $\mathrm{NO}_{3}^{-}$converted into $\mathrm{NO}_{2}^{-}$, six electrons per $\mathrm{NO}_{2}{ }^{-}$converted into $\mathrm{NH}_{4}{ }^{+}$and two electrons and one ATP per molecule of $\mathrm{NH}_{4}^{+}$converted into glutamate (BLOOM; SUKRAPANNA; WARNER, 1992).

At the tasselling stage (VT) under low $\mathrm{N}$ availability, the presence of severe multicollinearity was diagnosed between the explicative characteristics related to the condition of low $\mathrm{N}$ availability in the phenotypic correlation matrix for the path analysis. Since all the characteristics are potentially important and cannot be eliminated, path analysis for this level of $\mathrm{N}$ was performed under multicollinearity (CARVALHO; CRUZ, 1996).

Table 1 - Estimates of the direct and indirect effects between the main dependent variable, NUpE at stage R6, and the independent explicative variables, GSs, LRAxi and TP, in three strains of maize evaluated under low nitrogen availability (LN), at stage V9, Viçosa, MG, Brazil

\begin{tabular}{lcc}
\hline \multicolumn{1}{c}{ Characteristic } & Effects of Association & Estimate \\
\hline \multirow{2}{*}{$\mathrm{GSs}^{2}$} & Direct effect on NUpE & 2.55 \\
& Indirect effect through LRAxi & -1.39 \\
\hline Total & Indirect effect through TP & -1.33 \\
\hline & & -0.17 \\
LRAxi $^{3}$ & Direct effect on NUpE & 1.63 \\
& Indirect effect through GSs & -2.17 \\
\hline Total & Indirect effect through TP & 1.20 \\
\hline & & 0.66 \\
TP & & -1.34 \\
& Direct effect on NUpE & 2.54 \\
\hline Total & Indirect effect through GSs & -1.47 \\
\hline Coefficient of Determination & Indirect effect through LRAxi & -0.26 \\
Effect of residual variable & & 0.99 \\
\hline
\end{tabular}

${ }^{1}$ Nitrogen uptake efficiency. ${ }^{2}$ Glutamine synthetase activity in the shoots $\left(\mu\right.$ moles $\left.\mathrm{GHD} \mathrm{h}^{-1} \mathrm{~g}^{-1} \mathrm{FW}\right) .{ }^{3}$ Axial root length $(\mathrm{cm}) .{ }^{4}$ Level of phosphorus $\left(\right.$ dag $\left.\mathrm{kg}^{-1}\right)$

Table 2 - Estimates of the direct and indirect effects between the main dependent variable, NUpE at stage R6, and the independent explicative variables, TP and TK in three strains of maize evaluated under low nitrogen availability (LN), at stage V14, Viçosa, MG, Brazil

\begin{tabular}{lcc}
\hline \multicolumn{1}{c}{ Characteristic } & Effects of Association & Estimate \\
\hline $\mathrm{TP}^{2}$ & Direct effect on NUpE & 0.76 \\
& Indirect effect through TK & -0.15 \\
\hline Total & Direct effect on NUpE & 0.61 \\
\hline $\mathrm{TK}^{3}$ & Indirect effect through TP & -0.80 \\
\hline Total & & 0.14 \\
\hline Coefficient of Determination & -0.66 \\
Effect of residual variable & & 1.00 \\
\hline
\end{tabular}

${ }^{1}$ Nitrogen uptake efficiency. ${ }^{2}$ Level of phosphorus $(\mathrm{dag} \mathrm{kg}-1) .{ }^{3}$ Level of potassium $\left(\mathrm{dag} \mathrm{kg}^{-1}\right)$ 
The value for the constant $\mathrm{k}$ chosen for stabilisation of the estimates was relatively small $(0.05)$, producing little bias in the regression analysis. This can be seen by the high coefficient of determination of the path analysis $\left(R^{2}=0.98\right)$, showing that most of the variation in the principle characteristic was determined by the explicative characteristics (Table 3). It was seen that correlation was negative (-0.99) between the NUtE and the NUpE, possibly because the plant prioritises one component over the other during its development. This is because maize plants in the early stages of development probably absorb more nutrients than they use. The NUpE therefore becomes the most important component in these early stages of the cycle. However, in the course of development, the use component sees an increase in importance at the expense of uptake. The negative direct effects of LRAxi (-0.22) and LRLat (-0.23) are contrary to the expected increase in $\mathrm{N}$ uptake from the increase in root length. This may be due to the plant expending an excess of energy on root growth, decreasing availability for absorption.

At this stage (VT), it is also known that GSr has both a moderate direct effect (0.14) on NUpE and a high correlation (0.64), and can also be used as a characteristic in preparing selection indices for plants with high NUpE. This demonstrates that assimilation of $\mathrm{N}$ occurs not only in the leaves, but also in the roots. However, for this to occur, it is necessary to import carbohydrates produced in the leaves, so that after being metabolised they can generate energy and provide carbon skeletons for the process of nitrogen incorporation into amino acids (OAKS, 1994), the process expending more energy compared to assimilation in the leaves. This energy advantage is the basis of the suggestion for selecting strains that maximise the reduction of $\mathrm{NO}_{3}^{-}$in the leaves, with a view to reducing energy requirements and increasing productivity. One proviso that must be made, is that from this stage on, there is no longer a way to maintain only superior plants for hybridisation, thereby reducing selection gain. In addition, the characteristics that explained the $\mathrm{NUpE}$ are destructive, hindering the process of rapid evaluation, and making it impossible for the materials evaluated to be used as units for recombination. There will consequently be a reduction in any potential gains to be made from the selection.

At the R1 stage under low $\mathrm{N}$ availability, the characteristics considered in the path analysis also explain almost all of the total variation in $\mathrm{NUpE}$ $\left(\mathrm{R}^{2}=0.98\right)$ (Table 4). For this case there was also severe multicollinearity in the phenotypic correlation matrix, the path analysis being performed under multicollinearity with the value of $\mathrm{k}$ equal to that in the previous analysis (0.05). It was seen that the direct effect of GSs on the NUpE decreased when compared to the V9 stage (0.33). However, there was an increase in correlation (0.87), reconfirming the significance of the interaction, strain $\mathrm{x}$ evaluation stage. Root length had a direct effect on the NUpE similar to that seen at the VT stage.

Table 3 - Estimates of the direct and indirect effects between the main dependent variable, NUpE at stage R6, and the independent explicative variables, NUtE, NUE, LRLat, LRAxi, NL and GSr in three strains of maize evaluated under low nitrogen availability (LN), at stage VT, Viçosa, MG, Brazil

\begin{tabular}{lccc}
\hline Characteristic & Effects of Association & Estimate & VIF* $^{*}$ \\
\hline & Direct effect on NUpE & -0.23 & 16.80 \\
& Indirect effect through NUE & -0.23 & 15.22 \\
NUtE $^{2}$ & Indirect effect through LRLat & -0.23 & 14.87 \\
& Indirect effect through LRAxi & -0.22 & 14.81 \\
& Indirect effect through NL & $-8 \mathrm{E}-4$ & 0.07 \\
& Indirect effect through GSr & -0.08 & 3.94 \\
\hline Total & & -0.99 & \\
\hline \multirow{4}{*}{ NUE $^{3}$} & Direct effect on NUpE & -0.23 & 16.82 \\
& Indirect effect through NUtE & -0.23 & 15.20 \\
& Indirect effect through LRLat & -0.23 & 14.76 \\
& Indirect effect through LRAxi & -0.22 & 14.69 \\
\hline Total & Indirect effect through NL & $-5 \mathrm{E}-4$ & 0.03 \\
\hline & Indirect effect through GSr & -0.08 & 4.28 \\
\hline
\end{tabular}


Table 3 Continuation

\begin{tabular}{|c|c|c|c|}
\hline \multirow{6}{*}{ LRLat $^{4}$} & Direct effect on NUpE & -0.23 & 16.58 \\
\hline & Indirect effect through NUtE & -0.23 & 15.06 \\
\hline & Indirect effect through NUE & -0.23 & 14.97 \\
\hline & Indirect effect through LRAxi & -0.22 & 15.01 \\
\hline & Indirect effect through NL & $-2 \mathrm{E}-3$ & 0.29 \\
\hline & Indirect effect through GSr & -0.07 & 2.90 \\
\hline \multicolumn{2}{|l|}{ Total } & -0.98 & \\
\hline \multirow{6}{*}{ LRAxi $^{5}$} & Direct effect on NUpE & -0.22 & 16.57 \\
\hline & Indirect effect through NUtE & -0.23 & 15.02 \\
\hline & Indirect effect through NUE & -0.22 & 14.91 \\
\hline & Indirect effect through LRLat & -0.23 & 15.02 \\
\hline & Indirect effect through NL & $-2 \mathrm{E}-3$ & 0.34 \\
\hline & Indirect effect through GSr & -0.07 & 2.77 \\
\hline \multicolumn{2}{|l|}{ Total } & -0.98 & \\
\hline \multirow{6}{*}{$\mathrm{NL}^{6}$} & Direct effect on NUpE & -0.01 & 8.96 \\
\hline & Indirect effect through NUtE & -0.02 & 0.12 \\
\hline & Indirect effect through NUE & -0.01 & 0.05 \\
\hline & Indirect effect through LRLat & -0.04 & 0.55 \\
\hline & Indirect effect through LRAxi & -0.05 & 0.62 \\
\hline & Indirect effect through GSr & 0.10 & 6.24 \\
\hline \multicolumn{2}{|l|}{ Total } & -0.03 & \\
\hline \multirow{6}{*}{$\mathrm{GSr}^{7}$} & Direct effect on NUpE & 0.14 & 12.32 \\
\hline & Indirect effect through NUtE & 0.14 & 5.37 \\
\hline & Indirect effect through NUE & 0.14 & 5.84 \\
\hline & Indirect effect through LRLat & 0.12 & 3.91 \\
\hline & Indirect effect through LRAxi & 0.11 & 3.73 \\
\hline & Indirect effect through NL & -0.01 & 4.53 \\
\hline \multicolumn{2}{|l|}{ Total } & 0.64 & \\
\hline \multicolumn{2}{|c|}{ Coefficient of Determination } & 0.98 & \\
\hline \multicolumn{2}{|c|}{ Value of $\mathrm{k}$} & 0.05 & \\
\hline \multicolumn{2}{|c|}{ Effect of residual variable } & 0.11 & \\
\hline
\end{tabular}

* Variance inflation fator. ${ }^{1}$ Nitrogen uptake efficiency. ${ }^{2}$ Nitrogen usage efficiency ${ }^{3}$ Nitrogen use efficiency. ${ }^{4}$ Lateral root length (cm). ${ }^{5}$ Axial root length $(\mathrm{cm}) .{ }^{6}$ Number of leaves. ${ }^{7}$ Glutamine synthetase activity in the roots ( $\mu$ moles $\left.\mathrm{GHD} \mathrm{h}^{-1} \mathrm{~g}^{-1} \mathrm{FW}\right)$

Table 4 - Estimates of the direct and indirect effects between the main dependent variable, NUpE at stage R6, and the independent explicative variables, GSs, LRLat, LRAxi and NL in three strains of maize evaluated under low nitrogen availability (LN), at stage R1, Viçosa, MG, Brazil

\begin{tabular}{lccc}
\hline \multicolumn{1}{c}{ Characteristic } & Effects of Association & Estimate & VIF* $^{*}$ \\
\hline & Direct effect on NUpE & 0.33 & 12.01 \\
$\mathrm{GSs}^{2}$ & Indirect effect through LRLat & 0.30 & 8.22 \\
& Indirect effect through LRAxi & 0.20 & 4.62 \\
& Indirect effect through NL & $5 \mathrm{E}-3$ & 1.56 \\
\hline Total & & 0.87 & \\
\hline
\end{tabular}


Table 4 Continuation

\begin{tabular}{lccc}
\hline & Direct effect on NUpE & -0.37 & 13.53 \\
\multirow{2}{*}{ LRLat $^{3}$} & Indirect effect through GSs & -0.27 & 7.29 \\
& Indirect effect through CRAxi & -0.34 & 10.63 \\
& Indirect effect through NF & $-7 \mathrm{E}-4$ & 0.03 \\
\hline Total & & -0.99 & 12.65 \\
& Direct effect on NUpE & -0.35 & 4.39 \\
LRAxi $^{4}$ & Indirect effect through GSs & -0.21 & 11.38 \\
& Indirect effect through LRLat & -0.36 & 0.68 \\
\hline Total & Indirect effect through NL & $3 \mathrm{E}-3$ & 6.58 \\
\hline & & -0.93 & 2.86 \\
NL & & -0.01 & 0.07 \\
& Direct effect on NUpE & -0.17 & 1.31 \\
\hline Total & Indirect effect through GSs & 0.03 & \\
\hline Coefficient of Determination & Indirect effect through LRLat & 0.12 & \\
Value of k & Indirect effect through LRAxi & -0.03 & \\
Effect of residual variable & & 0.98 & \\
\hline
\end{tabular}

* Variance inflation fator. ${ }^{1}$ Nitrogen uptake efficiency. ${ }^{2}$ Glutamine synthetase activity in the roots $\left(\mu \mathrm{moles}\right.$ GHD h $\left.{ }^{-1} \mathrm{~g}^{-1} \mathrm{FW}\right) .{ }^{3}$ Lateral root length (cm). ${ }^{4}$ Axial root length (cm). ${ }^{5}$ Number of leaves

\section{Gains from selection}

Considering the direct and indirect gains estimated for NUpE at stage R6 under LN, it can be seen that the greatest gain would be obtained by selecting for GSs at stage R1 - a fairly advanced stage in the plant cycle (Table 5). However, it is of great interest that the evaluation be made early, as this speeds up the selection process, with the least efficient genotypes being discarded immediately and consequently only superior individuals being interbred. (FRITSCHENETO et al., 2010). It therefore follows that GSs at V9, with an estimated gain of $83.55 \%$, is the most promising characteristic for indirect, early selection in this environment. In addition to its high heritability $(82.9 \%$, data not shown), as the method is nondestructive, it is possible to evaluate the recombination units themselves, maximizing control over the parents and the gains when selecting for $\mathrm{NUpE}$ at the end of the cycle.

Under HN, GSr at stage V14 was the characteristic which made possible a greater indirect gain of the NUpE in a stress environment at the end of the cycle (206.86\%) (Table 6). In addition, selection at stage V14 makes it possible to keep only superior individuals for the recombination process. In an $\mathrm{HN}$ environment, there is also the advantage of the plants fully expressing their genetic potential, with the possibility of evaluating other variables of interest to commercial farming, such as lodging and resistance to disease.

The enzyme NR was not so important in the selection of superior genotypes as the NUE. Similar results were observed by Oliveira et al. (2013), where the activity of the enzyme did not differentiate between varieties which were efficient or inefficient in the use of N. In the present work, NR activity was also not influenced by $\mathrm{N}$ levels. This shows that high NR activity does not necessarily result in high NUE, seeing that NR is only the first enzyme in a long process of assimilation. On the other hand, GSs is the characteristic with the greatest effect on $\mathrm{NUpE}$, and is consequently of interest in the evaluation of genotypes for NUE. Some authors (FONTAINE et al., 2009; MARTIN et al., 2006) have confirmed that quantitative trait loci (QTL) identified for grain yield and its components, coincide with QTL identified for GS activity. Furthermore, it has been demonstrated in maize and rice mutants that GS is necessary for grain filling in the presence and absence of N (HIREL et al., 2007). Thus, selecting for GSs activity will result in plants which are more efficient in the use of nitrogen and hence have higher yields. 
Table 5 - Estimates of direct (GSd) and indirect (GSi) gains (\%) with selection for the characteristics: GSs, LRAxi and TP at stage V9; TP and TK at stage V14; NUtE, NUE, LRLat, LRAxi and GSs at stage VT; and GSs, LRLat and LRAxi at stage R1, on NUpE at stage R6, in three strains of maize evaluated under low nitrogen availability (LN), in Viçosa, MG, Brazil

\begin{tabular}{|c|c|c|c|c|c|}
\hline Selection & Selection Stage & Selection Characteristic & Response Characteristic & Response Stage & $\mathrm{GS} \%$ \\
\hline \multirow{3}{*}{ Indirect } & \multirow{3}{*}{$\mathrm{V} 9^{4}$} & $\mathrm{GSs}^{1}$ & \multirow{3}{*}{ NUpE } & \multirow{3}{*}{ R6 } & 83.55 \\
\hline & & LRAxi $^{2}$ & & & 40.19 \\
\hline & & $\mathrm{TP}^{3}$ & & & 27.25 \\
\hline \multirow{2}{*}{ Indirect } & \multirow{2}{*}{ V14 } & $\mathrm{TP}$ & \multirow{2}{*}{ NUpE } & \multirow{2}{*}{ R6 } & 43.92 \\
\hline & & $\mathrm{TK}^{5}$ & & & 34.60 \\
\hline \multirow{5}{*}{ Indirect } & \multirow{5}{*}{$\mathrm{VT}^{11}$} & $\mathrm{NUtE}^{7}$ & \multirow{5}{*}{ NUpE } & \multirow{5}{*}{ R6 } & 53.49 \\
\hline & & $\mathrm{NUE}^{8}$ & & & 125.42 \\
\hline & & LRLat $^{9}$ & & & -0.21 \\
\hline & & LRAxi & & & -3.26 \\
\hline & & $\mathrm{GSr}^{10}$ & & & 158.60 \\
\hline \multirow{3}{*}{ Indirect } & \multirow{3}{*}{$\mathrm{R} 1^{12}$} & GSs & \multirow{3}{*}{ NUpE } & \multirow{3}{*}{ R6 } & 179.44 \\
\hline & & LRLat & & & 2.63 \\
\hline & & LRAxi & & & -1.04 \\
\hline Direct & $\mathrm{R} 6^{14}$ & $\mathrm{NUpE}^{13}$ & NUpE & R6 & 10.91 \\
\hline
\end{tabular}

${ }^{1}$ Glutamine synthetase activity in the shoots $\left(\mu\right.$ moles $\left.\mathrm{GHD} \mathrm{h}^{-1} \mathrm{~g}^{-1} \mathrm{FW}\right) .{ }^{2}$ Axial root length $(\mathrm{cm}) .{ }^{3}$ Phosphorus content $\left(\mathrm{dag} \mathrm{kg}{ }^{-1}\right) .{ }^{4} \mathrm{Nine}$ fully developed leaves. ${ }^{5}$ Potassium content $\left(\mathrm{dag} \mathrm{kg}{ }^{-1}\right) .{ }^{6}$ Fourteen fully developed leaves. ${ }^{7}$ Nitrogen usage efficiency. ${ }^{8}$ Nitrogen use efficiency. ${ }^{9}$ Lateral root length $(\mathrm{cm}) .{ }^{10}$ Glutamine synthetase activity in the roots $\left(\mu\right.$ moles $\left.\mathrm{GHD} \mathrm{h}{ }^{-1} \mathrm{~g}^{-1} \mathrm{FW}\right) .{ }^{11}$ Tasselling. ${ }^{12}$ Flowering. ${ }^{13}$ Nitrogen uptake efficiency. ${ }^{14}$ Physiological maturity

Table 6 - Estimates of direct (GSd) and indirect (GSi) gains (\%) with selection for the characteristics: NUpE, NUE, CRAxi, TP and TK at stage V9; NUpE, NUE, GSs, LRLat, LRAxi and TP at stage V14; NUpE, LRLat, LRAxi, TP and TK at stage VT; and TP at stage R6, on NUpE at stage R6, in three strains of maize evaluated under high nitrogen availability (HN), in Viçosa, MG, Brazil

\begin{tabular}{|c|c|c|c|c|c|}
\hline Selection & Selection Stage & Selection Characteristic & Response Characteristic & Response Stage & $\mathrm{GS} \%$ \\
\hline \multirow{5}{*}{ Indirect } & \multirow{5}{*}{ V9 $9^{6}$} & $\mathrm{NUpE}^{1}$ & \multirow{5}{*}{ NUpE } & \multirow{5}{*}{ R6 } & 75.71 \\
\hline & & $\mathrm{NUE}^{2}$ & & & 14.57 \\
\hline & & LRAxi $^{3}$ & & & 9.69 \\
\hline & & $\mathrm{TP}^{4}$ & & & 28.76 \\
\hline & & $\mathrm{TK}^{5}$ & & & 12.50 \\
\hline \multirow{6}{*}{ Indirect } & \multirow{6}{*}{ V14 } & $\mathrm{NUpE}$ & \multirow{6}{*}{ NUpE } & \multirow{6}{*}{ R6 } & 33.21 \\
\hline & & NUE & & & 13.05 \\
\hline & & $\mathrm{GSs}^{7}$ & & & 206.86 \\
\hline & & LRLat $^{8}$ & & & 6.28 \\
\hline & & LRAxi & & & 12.01 \\
\hline & & $\mathrm{TP}$ & & & 39.39 \\
\hline \multirow{5}{*}{ Indirect } & \multirow{5}{*}{$\mathrm{VT}^{10}$} & NUpE & \multirow{5}{*}{ NUpE } & \multirow{5}{*}{ R6 } & 151.43 \\
\hline & & LRLat & & & 37.96 \\
\hline & & LRAxi & & & 30.80 \\
\hline & & $\mathrm{TP}$ & & & 41.77 \\
\hline & & TK & & & 34.81 \\
\hline Indirect & \multirow{2}{*}{$\mathrm{R} 6^{11}$} & $\mathrm{TP}$ & \multirow{2}{*}{$\mathrm{NUpE}$} & \multirow{2}{*}{ R6 } & 27.01 \\
\hline Direct & & $\mathrm{NUpE}$ & & & 0.23 \\
\hline
\end{tabular}

${ }^{1}$ Nitrogen uptake efficiency. ${ }^{2}$ Nitrogen use efficiency. ${ }^{3}$ Axial root length $(\mathrm{cm}) \cdot{ }^{4}$ Phosphorus content $\left(\mathrm{dag} \mathrm{kg}^{-1}\right) \cdot{ }^{5}$ Potassium content $\left(\right.$ dag kg $\left.{ }^{-1}\right) \cdot{ }^{6}$ Nine fully developed leaves. ${ }^{7}$ Glutamine synthetase activity in the shoots $\left(\mu\right.$ moles $\left.\mathrm{GHD} \mathrm{h}{ }^{-1} \mathrm{~g}^{-1} \mathrm{FW}\right) .{ }^{8}$ Lateral root length $(\mathrm{cm}) .{ }^{9}$ Fourteen fully developed leaves. ${ }^{10}$ Tasselling. ${ }^{11}$ Physiological maturity 


\section{CONCLUSION}

The activities of glutamine synthetase at stages V9 and V14 allow early indirect selection for nitrogen use efficiency in maize under conditions of low and high $\mathrm{N}$ availability respectively.

\section{ACKNOWLEDGEMENT}

The authors wish to thank FAPEMIG for a scholarship grant and for funding the research project (CAG - APQ-00559-12).

\section{REFERENCES}

ALVES, V. M. C. et al. Efeito da omissão de fósforo na absorção de nitrogênio por híbridos de milho (Zea mays, L.). Revista Ceres, v. 43, n. 248, p. 435-443, 1996.

BLOOM, A. J.; SUKRAPANNA, S. S.; WARNER, R. L. Root respiration associated with ammonium and nitrate absorption and assimilation by barley. Plant Physiology, v. 99, n. 04, p. 1294-1301, 1992.

CARVAlHO, S. P.; CRUZ, C. D. Diagnosis of multicollinearity: assessment of the condition of correlation matrices used in genetic studies. Revista Brasileira de Genética, v. 19, n. 03, p. 479-484, 1996.

CHEN, J. Y. et al. Identification of QTLs for phosphorus utilization efficiency in maize (Zea mays L.) across P levels. Euphytica, v. 167, n. 02, p. 245-252, 2009.

CRUZ, C. D. GENES - a software package for analysis in experimental statistics and quantitative genetics. Acta Scientiarum, v. 35, n. 03, p. 271-276, 2013.

DOVALE, J. C.; FRITSCHE-NETO, R. Genetic control of traits associated with phosphorus use efficiency in maize by REML/BLUP. Revista Ciência Agronômica, v. 44, n. 03, p. 554-563, 2013.

DOVALE, J. C. et al. Efeitos gênicos de caracteres associados à eficiência no uso de nitrogênio em milho. Pesquisa Agropecuária Brasileira, v. 47, n. 03, p. 385-392, 2012.

DUARTE, A. et al. Acúmulo de massa seca e nutrientes em cultivares de milho originárias de clima tropical e introduzidas de clima temperado. Revista Brasileira de Milho e Sorgo, v. 02, n. 03, p. 1-20, 2003.

FONTAINE, J. X. et al. A quantitative genetic study for elucidating the contribution of glutamine synthetase, glutamate dehydrogenase and other nitrogen-related physiological traits to the agronomic performance of common wheat. Theoretical and Applied Genetics, v. 119, n. 04, p. 645-662, 2009.
FRITSCHE-NETO, R.; BORÉM, A. Melhoramento de plantas para condições de estresses abióticos.Viçosa: Editora UFV, 2011. 250 p.

FRITSCHE-NETO, R. et al. Herança de caracteres associados à eficiência de utilização do fósforo em milho. Pesquisa Agropecuária Brasileira, v. 45, n. 05, p. 465-471, 2010.

GALLAIS, A.; HIREL, B. An approach to the genetics of nitrogen use efficiency in maize. Journal of Experimental Botany, v. 55, n. 396, p. 295-306, 2004.

HIREL, B. et al. The challenge of improving nitrogen use efficiency in crop plants: towards a more central role for genetic variability and quantitative genetics within integrated approaches. Journal of Experimental Botany, v. 58, n. 09, p. 2369-2387, 2007.

JAKELAITIS, A.; SILVA, A. A.; FERREIRA, L. R. Efeitos do nitrogênio sobre o milho cultivado em consórcio com Brachiaria brizantha. Acta Scientiarum Agronomy, v. 27, n. 01, p. 39-46, 2005.

MARTIN, A. et al. Two Cytosolic Glutamine Synthetase Isoforms of Maize Are Specifically Involved in the Control of Grain Production. The Plant Cell, v. 18, n. 11, p. 3252-3274, 2006.

MOLL, R. H.; KAMPRATH, E. L.; JACKSON, A. Analysis and interpretation of factors which contribute to efficiency of nitrogen utilization. Agronomy Journal, v. 74, n. 03, p. 562-564, 1982.

MONNEVEUX, P. et al. Population density and low nitrogen affects yield - associated traits in tropical maize. Crop Science, v. 45, n .02, p. 535-545, 2005.

OAKS, A. Efficiency of nitrogen utilization in $\mathrm{C} 3$ and $\mathrm{C} 4$ cereals. Plant Physiology, v. 106, n. 02, p. 407-414, 1994.

OLIVEIRA, L. R. et al. Eficiência na absorção e utilização de nitrogênio e atividade enzimática em genótipos de milho. Revista Ciência Agronômica, v. 44, n. 03, p. 614-621, 2013.

O'NEILL, P. M.; SHANAHAN, J. F.; SCHEPERS, J. S. Use of chlorophyll fluorescence assessments to differentiate corn hybrid response to variable water conditions. Crop Science, v. 46, n. 02 , p. 681-687, 2006.

PAVINATO, P.S. et al. Nitrogênio e potássio em milho irrigado: análise técnica e econômica da fertilização. Ciência Rural, v. 38, n. 02, p. 358-364, 2008.

RICHARDSON, A. E. et al. Acquisition of phosphorus and nitrogen in the rhizosphere and plant growth promotion by microorganisms. Plant and Soil, v. 321, n. 01-02, p. 305-339, 2009.

SAS INSTITUTE. SAS/STAT Software versão 9.1, Cary, 2003.

SILVA, S. M. et al. Atividade da enzima nitrato redutase em milho cultivado sob diferentes níveis de adubação nitrogenada e potássica. Ciência Rural, v. 41, n. 11, p. 1931-1937, 2011.

TRACHSEL, S. et al. Mapping of QTLs for lateral and axile root growth of tropical maize. Theoretical and Applied Genetics, v. 119, n. 08, p. 1413-1424, 2009. 